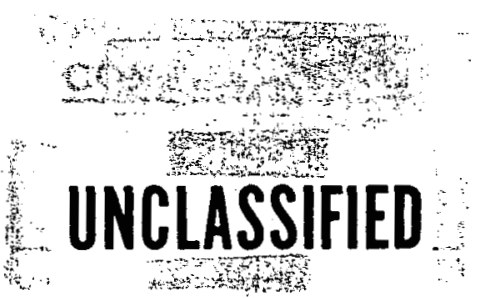

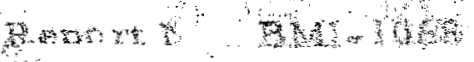

Contract No. W-7405-eng-92

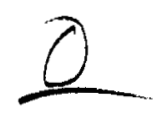

BMI-1068(Del.)

\title{
THE PROPERTIES OF URANIUM CONTAINING MINOR ADDITIONS OF CHROMIUM, SILICON, OR TITANIUM
}

by

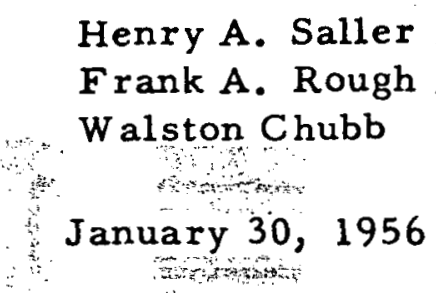

\begin{tabular}{ll|} 
Photostat Price $\$ \quad 4.80$ \\
Microfilm Price $\$ \quad 2.70$ \\
Available from the \\
Office of Technical Services \\
Department of Commerce \\
Washington 25, D.C.
\end{tabular}

(द्य

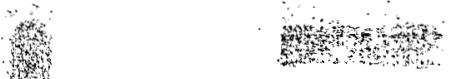

\section{LEGAL NOTICE}

This report was prepared as an account of Government sponsored work. Neither the United States, nor the Commission, nor any person acting on behalf of the Commission:

A. Makes any warranty or representation, express or implied, with respect to the occuracy, completeness, or usefulness of the information contained in this report, or thot the use of any information, apparatus, method, or process disclosed in this report may not infringe privately owned rights; or

B. Assumes any liabilities with respect to the use of, or for damages resulting from the use of any information, apparatus, method, or process disclosed in this report.

As used in the above, "person acting on behalf of the Commission" includes any employee or contractor of the Commission to the extent that such employee or contractor prepares, handles or distributes, or provides access to, any information pursuant to his employment or contract with the Commission.
\end{abstract}

This document is

PUBLICLY RELEASABLE 3 Stuel

Authorizing Official

Date: $4-17-07$

\section{$\mathrm{H}^{2}$}

BATTELLE MEMORIAL INSTITUTE

$505 \mathrm{King}$ Avenue

Columbus 1, Ohio 


\section{DISCLAIMER}

This report was prepared as an account of work sponsored by an agency of the United States Government. Neither the United States Government nor any agency Thereof, nor any of their employees, makes any warranty, express or implied, or assumes any legal liability or responsibility for the accuracy, completeness, or usefulness of any information, apparatus, product, or process disclosed, or represents that its use would not infringe privately owned rights. Reference herein to any specific commercial product, process, or service by trade name, trademark, manufacturer, or otherwise does not necessarily constitute or imply its endorsement, recommendation, or favoring by the United States Government or any agency thereof. The views and opinions of authors expressed herein do not necessarily state or reflect those of the United States Government or any agency thereof. 


\section{DISCLAIMER}

Portions of this document may be illegible in electronic image products. Images are produced from the best available original document. 


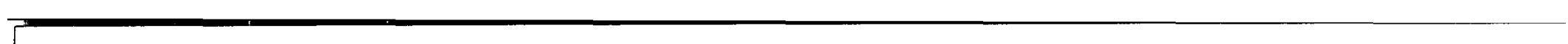


5 and 6

1

TABLE OF CONTENTS

$\underline{\text { Page }}$

ABSTRACT • . • . . . . . . . . . . . . . . . 7

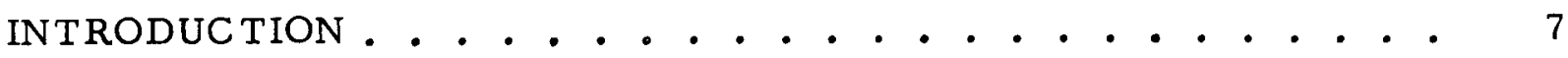

EXPERIMENTAL PROCEDURES AND RESULTS . • • . • . • . . 8

Preparation of Alloys . . . . . . . . . . . . . 8

Mechanical Properties . . . . . . . . . . . . 12

Physical Properties . . . . . . . . . . . . . . 12

Heat-Treatment Studies . . . . . . . . . . . 19

SUMMARY . . . . . . . . . . . . . . . . . . 31

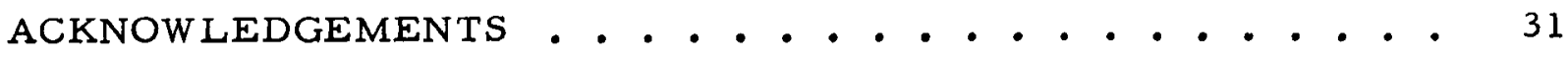




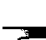

-

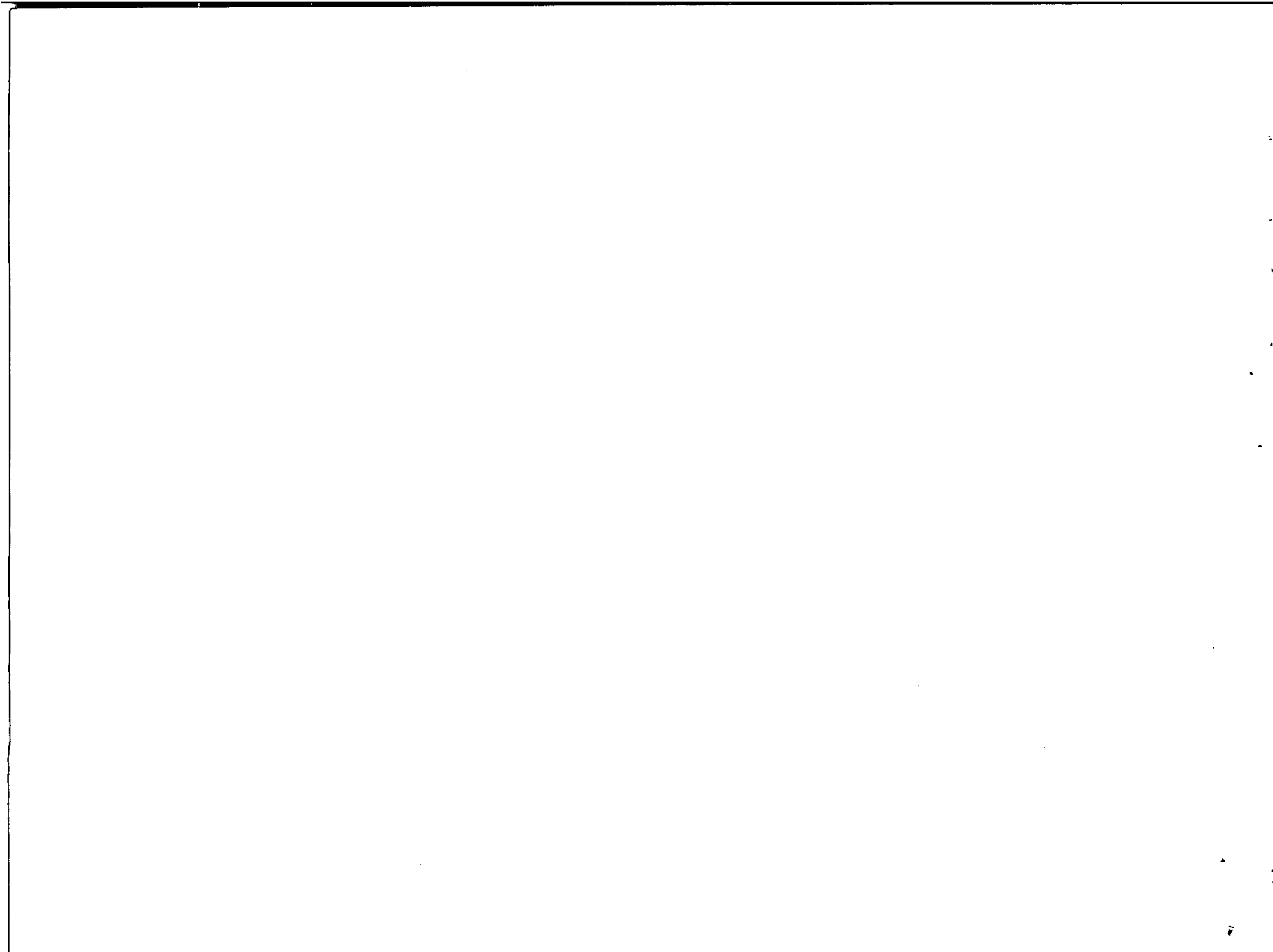

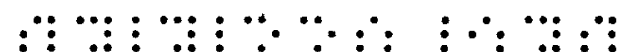


THE PROPERTIES OF URANIUM CONTAINING MINOR ADDITIONS OF EHROMIUM, SILICON, OR TITANIUM

Henry A. Saller, FrankA. Rough, and Walston Chubb

Tensile tests on alloys of uranium show that those containing 0.35 a chromium and 1.5 a $\%$ silicon are about 30 per cent stronger than arc or induction-melted uranium. The ductility of the $0.35 \mathrm{a} / \mathrm{o}$ chromium alloy is similar to that of arc-melted uranium, but the $1.5 \mathrm{a} / \mathrm{o}$ silicon alloy has only about two-thirds of the ductility of arc-melted uranium. A 0.5 a/o titanium alloy was not significantly different from uranium.

All alloys were found to have similar thermal conductivities and thermal-expansion properties.

Beta treatment of alpha-rolled stock was found to cause an increase in grain size and an increase in hardress in all alloys. Anneal ing the alloys at 600 C after beta quenching was found to soften the alloys and made the grains equiaxed without causing any change in grain size Microstructures show that arc melted uranium has a larger grain size and lower inclusion count than induction-melted waniume
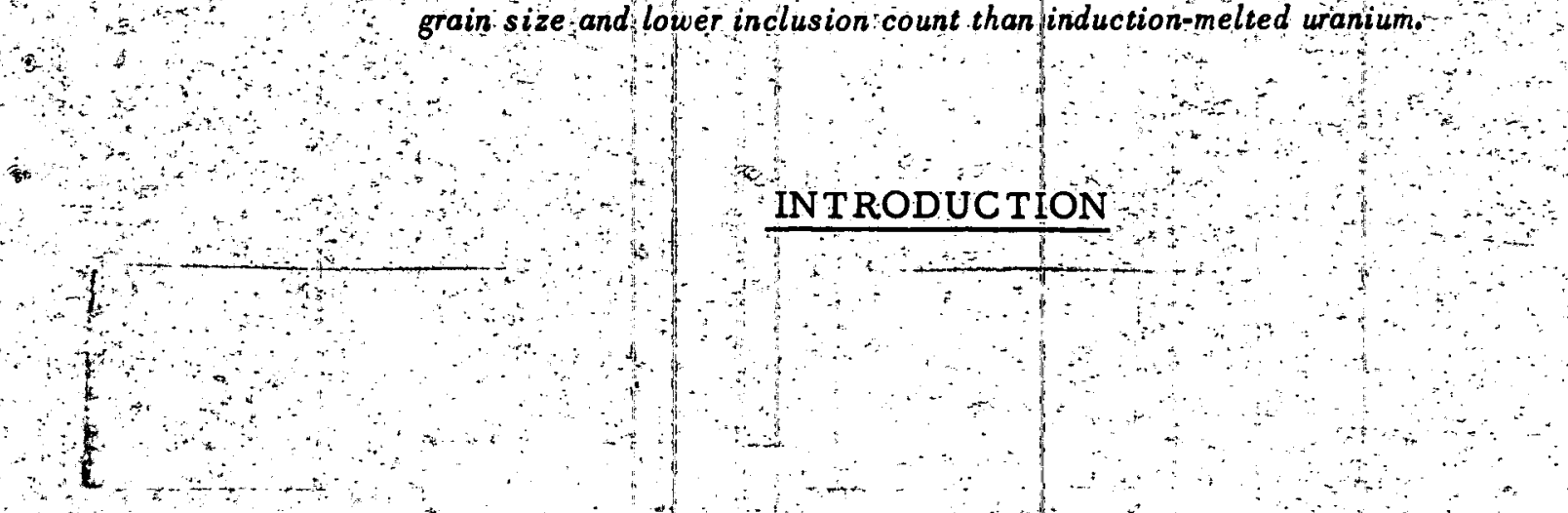

Several methods for improving the performance of fuel elements are being considered. These include changes in the geometry of the siug to re duce the themal stresses, improvements in metal quality such as a reduction in the number and size of nonmetallic inclusions, and alloying to. improve the mechanical properties of the base metal. The present study is related to the latter pos sibility.

The alloying elements which may be considered are limited to those having low neutron-absorption cross sections, and only dilute alloys are practical in present reactors. The alloys investigated were selected on the basis of early data indicating that small additions of chromium, silicon, or titanium have a refining effect on the grain size of beta-quenched uranium. The effects of small amounts of these elements on the mechanical and physical properties of uranium were studied in this investigation. 


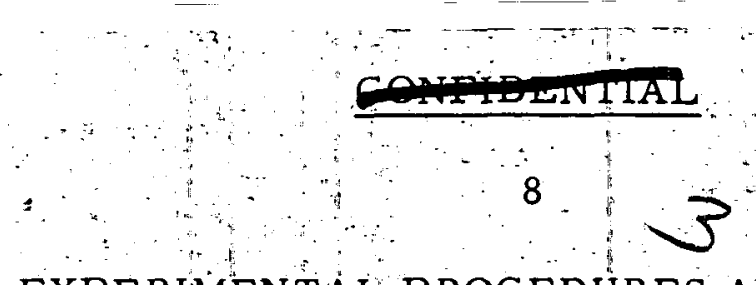

EXPERIMENTAL PROCEDURES AND RESULTS

\author{
Preparation of Alloys
}

Five alloys were prepared for this investigation. One alloy was prepared by induction melting biscuit uranium with no additional alloying elements. A second alloy was prepared by arc melting biscuit uranium with no alloying additions. The remaining alloys were prepared from coreduced biscuit alloy stock. These materials we re received from Mallinckrodt Chemical Co. as alloyed biscuit and were arc melted into suitable ingots. The analyses of the five alloys are shown in $\mathrm{T}$ able 1.

Another alloy containing nominally 1.5 a/o silicon and 0.5 a $/ 0$ titanium was prepared but was abandoned when it was shown that its microstructure and hardness were identical with those of the $1.5 \mathrm{a} / \mathrm{o}$ silicon alloy listed in Table 1 .

With-regard to the efficacy of the major alloying elements, it should be pointed out that chromium carbide is les stable than uranium carbide and that, therefore, chromium can be expected to appear in the uranium either solution or as metallic chromium. Silicon carbide is more stable than uranium carbide, but 1.4 a o silicon is enough silicon to combine with 100 ppm carbon and still leave about $1.2 \mathrm{a} / 0$ silicon available to form uranium silicide. On the other hand, titanium carbide is much more stable than uranium carbide and 0.4 a/o titanium is just enough titanium to conbine with 200 ppm carbon to form titanium carbide. Titanium carbide inclusions in a uranium alloy would be expected to have no greater effect on its properties than an equivalent amount of uranium carbide.

Ingots of each alloy, weighing 30 to $40 \mathrm{~kg}$, were forged in the gamma range to $1-1 / 2-i n$ - diameter bar stock. This stock was further reduced to 1-in. - and $1 / 2$-in. -diameter bars by hot rolling from salt baths at $620 \mathrm{C}$.

The hot-rolled alloys were given a basic heat treatment prior to mechanical and physical testing. The arc-melted uranium alloy, the induction-melted uranium alloy, the uranium-1.5 a/o silicon alloy, and the uranium- $0.5 \mathrm{a} /$ titanium alloy were heated to $730 \mathrm{C}$ in a lead bath for 15 min and water quenched. The uranium-0. 35 a $/ 0$ chromium alloy was heated to $730 \mathrm{C}$ in a lead bath for $15 \mathrm{~min}$, transferred to another lead bath at $550 \mathrm{C}$ for $20 \mathrm{~min}$, and water quenched. Typical structures and hardnesses produced by these treatments are shown in Figures $1,2,3,4$, and 5 .

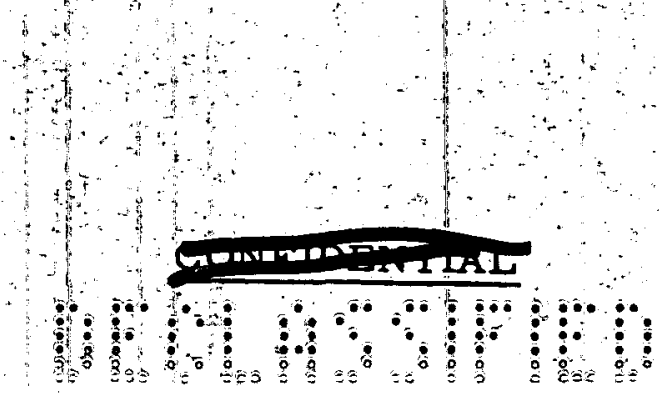




\section{4}

TABLE 1. URANIUM ALLOY ANALYSES

\begin{tabular}{|c|c|c|c|c|c|}
\hline \multirow{2}{*}{$\begin{array}{c}\text { Alloy } \\
\text { Identification } \\
\end{array}$} & \multicolumn{2}{|c|}{ Major Alloying Elements } & \multicolumn{3}{|c|}{ Nonmetallics, ppm } \\
\hline & $a / 0$ & $\mathrm{w} / \mathrm{o}$ & Carbon & Nitrogen & Hydrogen \\
\hline Arc-melted uranium & None & None & 50 & 40 & 4 \\
\hline Induction-melted uranium & None & None & 600 & 50 & 1 \\
\hline Uranium $-0.35 \mathrm{a} / \mathrm{o}$ chromium & 0.23 chromium & 0.05 chromium & 300 & 40 & 5 \\
\hline Uranium-1.5 a/o silicon & 1. 4 silic on & 0.17 silicon & 100 & 50 & 2 \\
\hline Uranium- -0.5 a/o titanium & 0.4 titanium & 0.08 titanium & 200 & 10 & 10 \\
\hline
\end{tabular}




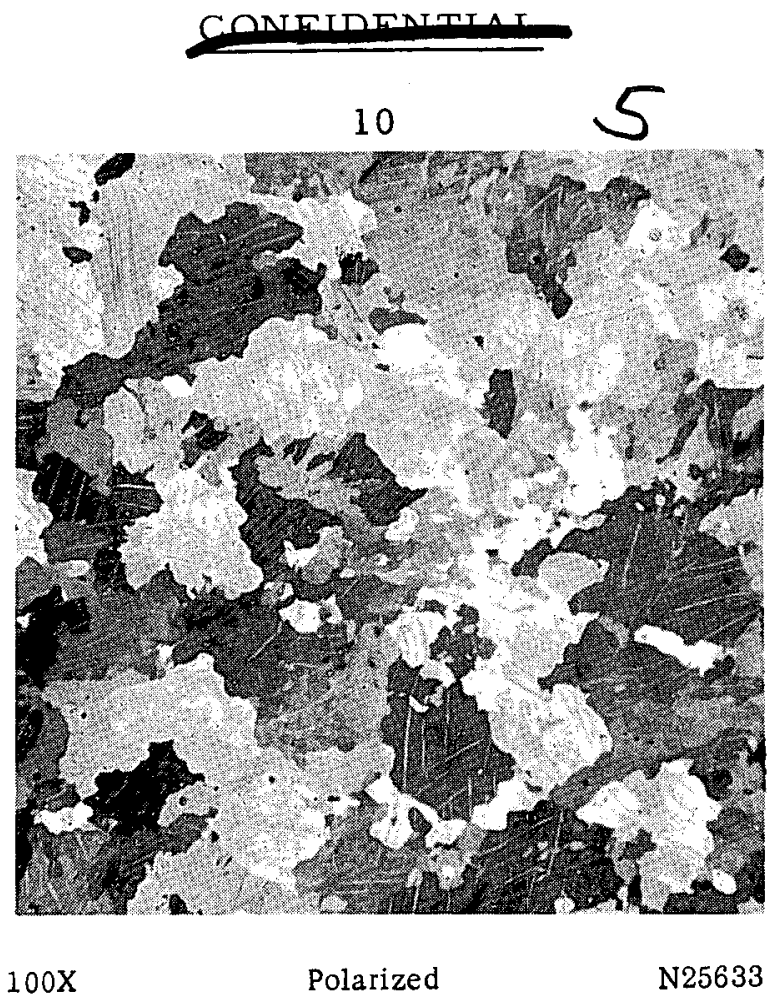

FIGURE 1. ARC-MELTED URANIUM

Hot rolled at $620 \mathrm{C}$

Heated $15 \mathrm{~min}$ at $730 \mathrm{C}$ and water quenched

Hardness $=230 \mathrm{DPH}$

Grain size $=0.10 \mathrm{~mm}$

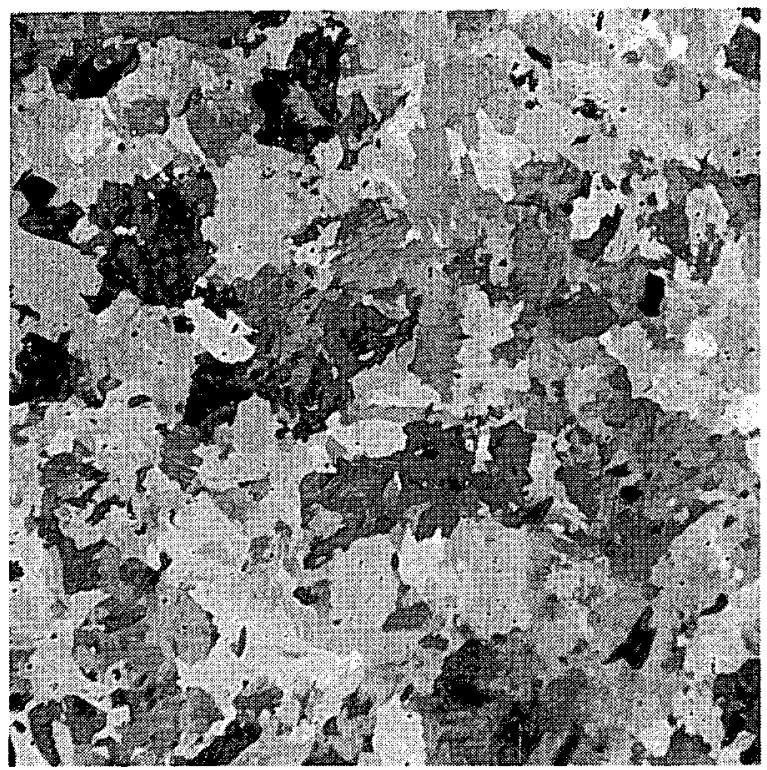

$100 \mathrm{X}$

Polarized

N25634

FIGURE 2. INDUCTION-MELTED URANIUM

Hot rolled at $620 \mathrm{C}$

Heated $15 \mathrm{~min}$ at $730 \mathrm{C}$ and water quenched Hardness $=280 \mathrm{DPH}$

Grain size $=0.05 \mathrm{~mm}$

\section{CONIEIDANTEIAT,}

| 


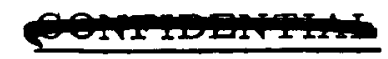

11
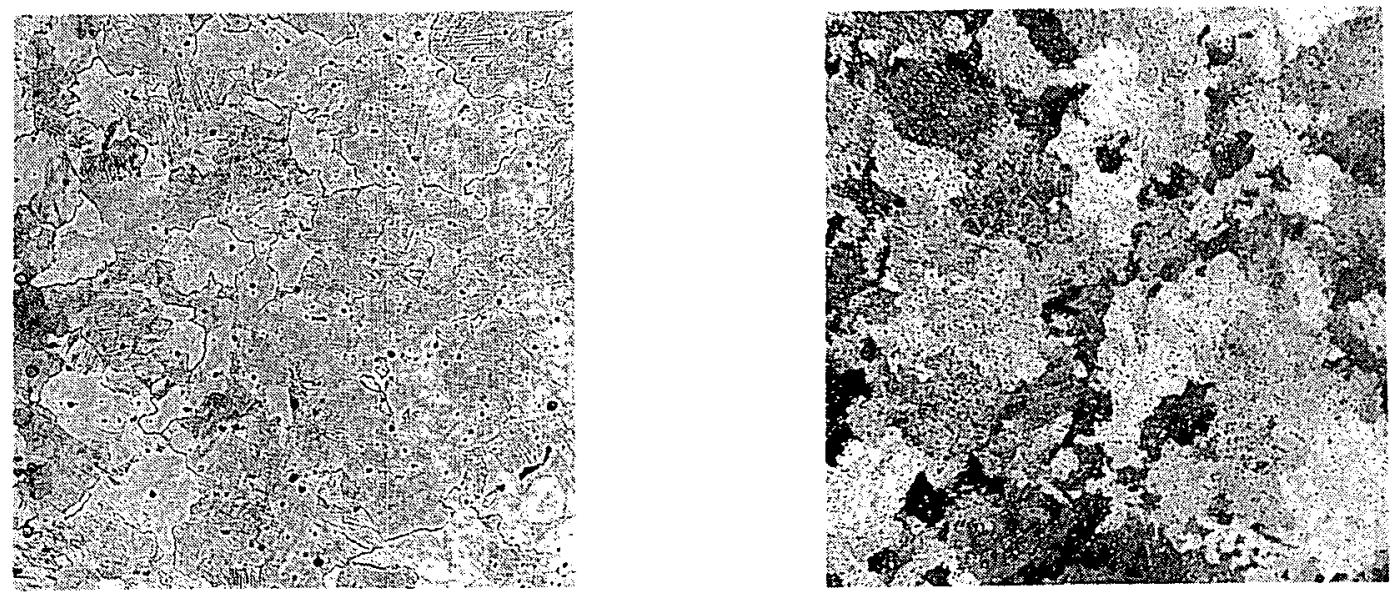

$100 \mathrm{X}$

Bright Field

N27538

$100 \mathrm{X}$

Polarized

N27539

FIGURE 3. ARC-MELTED URANIUM-0.35 a/o CHROMIUM

Hot rolled at $620 \mathrm{~F}$

Heated $15 \mathrm{~min}$ at $730 \mathrm{C}, 20 \mathrm{~min}$ at $550 \mathrm{C}$. and water quenched

Hardness $=290 \mathrm{DPH}$

FIGURE 4. ARC-MELTED URANIUM-1.5 a/o SILICON

Hot rolled at $620 \mathrm{C}$

Heated $15 \mathrm{~min}$ at $730 \mathrm{C}$ and water quenched

Hardness $=295 \mathrm{DPH}$

Grain size $=0.04 \mathrm{~mm}$

Grain size $=0.07 \mathrm{~mm}$

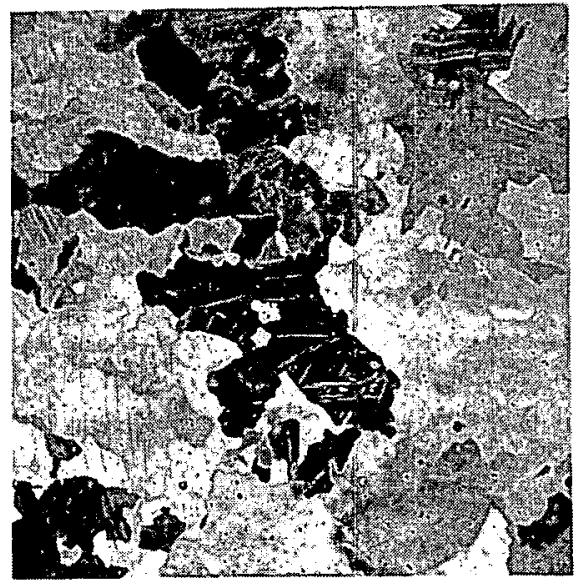

$100 \mathrm{X}$

Polarized

N27540

FIGURE 5. ARC-MELTED URANIUM-0.5 a /o TITANIUM

Hot rolled at $620 \mathrm{C}$

Heated $15 \mathrm{~min}$ at $730 \mathrm{C}$ and water quenched

Hardness $=240 \mathrm{DPH}$

Grain size $=0.07 \mathrm{~mm}$ 
Mechanical Properties 7

Tensile tests at room and elevated temperatures were run on 1/4-in.diameter test specimens with $2-1 / 4-$ in. - long reduced sections. The tests at $300 \mathrm{C}$ and $500 \mathrm{C}$ were run in a vacuum chamber. In most cases, only a single test was run at each temperature. All tests were run on a 20,000-1b Baldwin-Southwark universal testing machine. A clip-on extensometer with a 2-in. gage length was used to measure strain. This extensometer utilizes SR-4 gages on compression loops remote from the hot zone; its accuracy is plus or minus $0.0001 \mathrm{in}$./in. The results of the tensile tests are summarized in Figures $6,7,8,9$, and 10 . The chromium and silicon alloys are considerably stronger than unalloyed uranium at all temperatures shown. Chromium seems to have little or no effect on the ductility of uranium at this alloy content; however, $1.5 \mathrm{a} / 0$ silicon drastically decreases the ductility of uranium. Titanium seems to decrease the ductility and increase the elevated temperature strength of uranium. A marked ductility transition occurs in all these materials near room temperature. This effect may be related to some change in the number of available slip systems in the orthorhombic structure of uranium at this temperature. The ductility transition also causes a change in the mode of fracture of uranium at this temperature. Above room temperature the fractures are fibrous and fracture occurs with decreasing loads. Below room temperature the fractures are brittle and fracture occurs while the load is still rising. This means that with decreasing temperature, the maximum load obtained becomes more and more dependent upon the surface condition of the specimen; therefore, the ultimate strength obtained tends to become quite variable. The transition temperature as determined by ultimate strength will depend to some extent upon the surface finish of the tensile specimen.

Hardness tests at elevated temperatures were obtained by means of a Vickers indenter loaded with a $1-\mathrm{kg}$ load. These tests were performed in a vacuum chamber. The results of the tests are shown in Figure 11. The data are not sufficiently complete to allow accurate curves to be drawn, so the curves shown are drawn to conform to the general shape of other more complete data. The hardness data confirm the findings of the tensile tests to the extent that the chromium and silicon alloys are the hardest as well as the strongest of the alloys.

\section{$\underline{\text { Physical Properties }}$}

Thermal linear-expansion measurements were made by using a manual dilatometer and heating and cooling rates of about $3 \mathrm{C}$ per min. Specimens were protected by a vacuum of $1 \times 10^{-4} \mathrm{~mm}$ of mercury or better. These measurements showed that, within the limits of variation of 
8

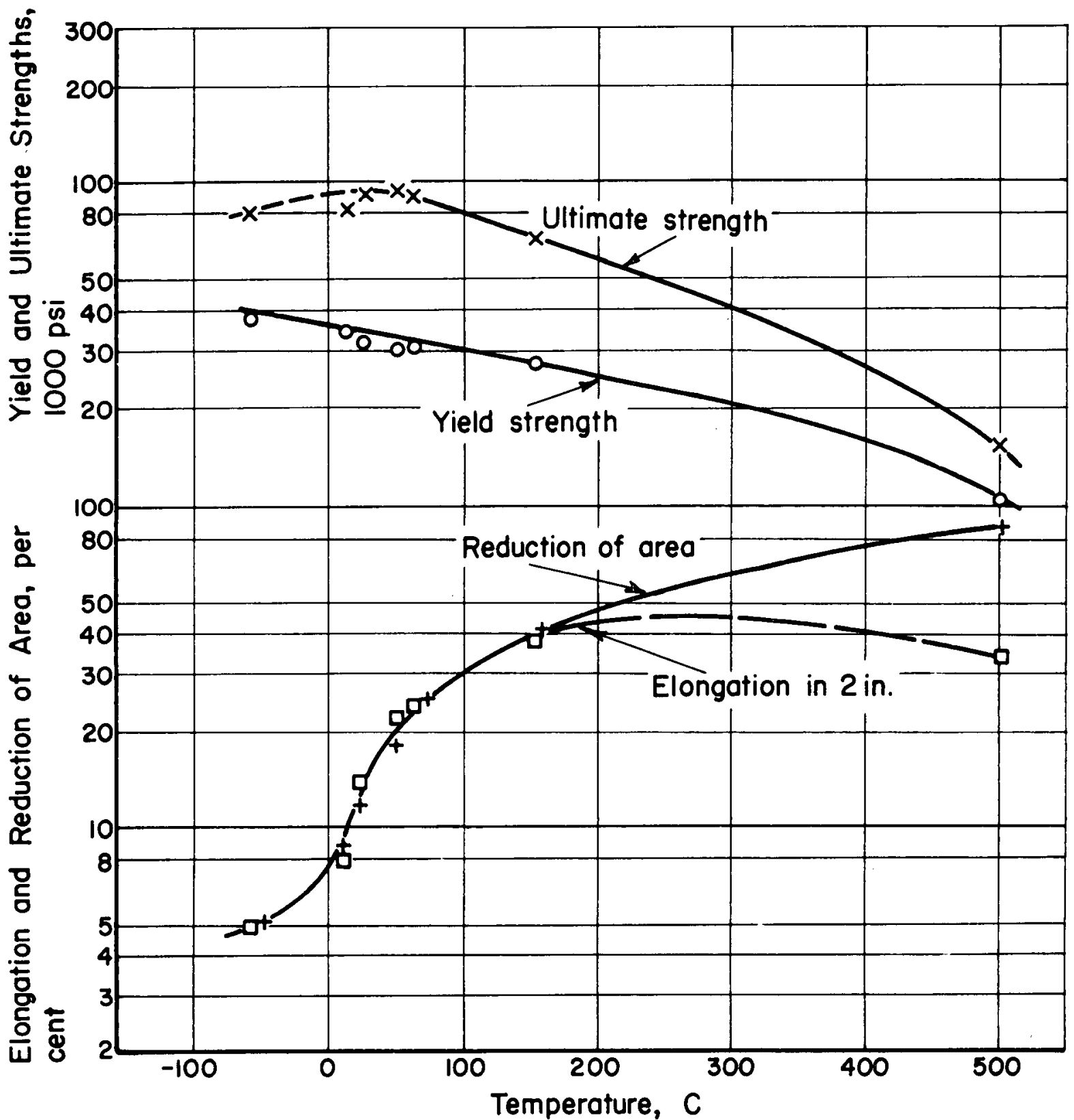

FIGURE 6. TENSILE PROPERTIES OF BETA-QUENCHED, ARC-MELTED URANIUM 


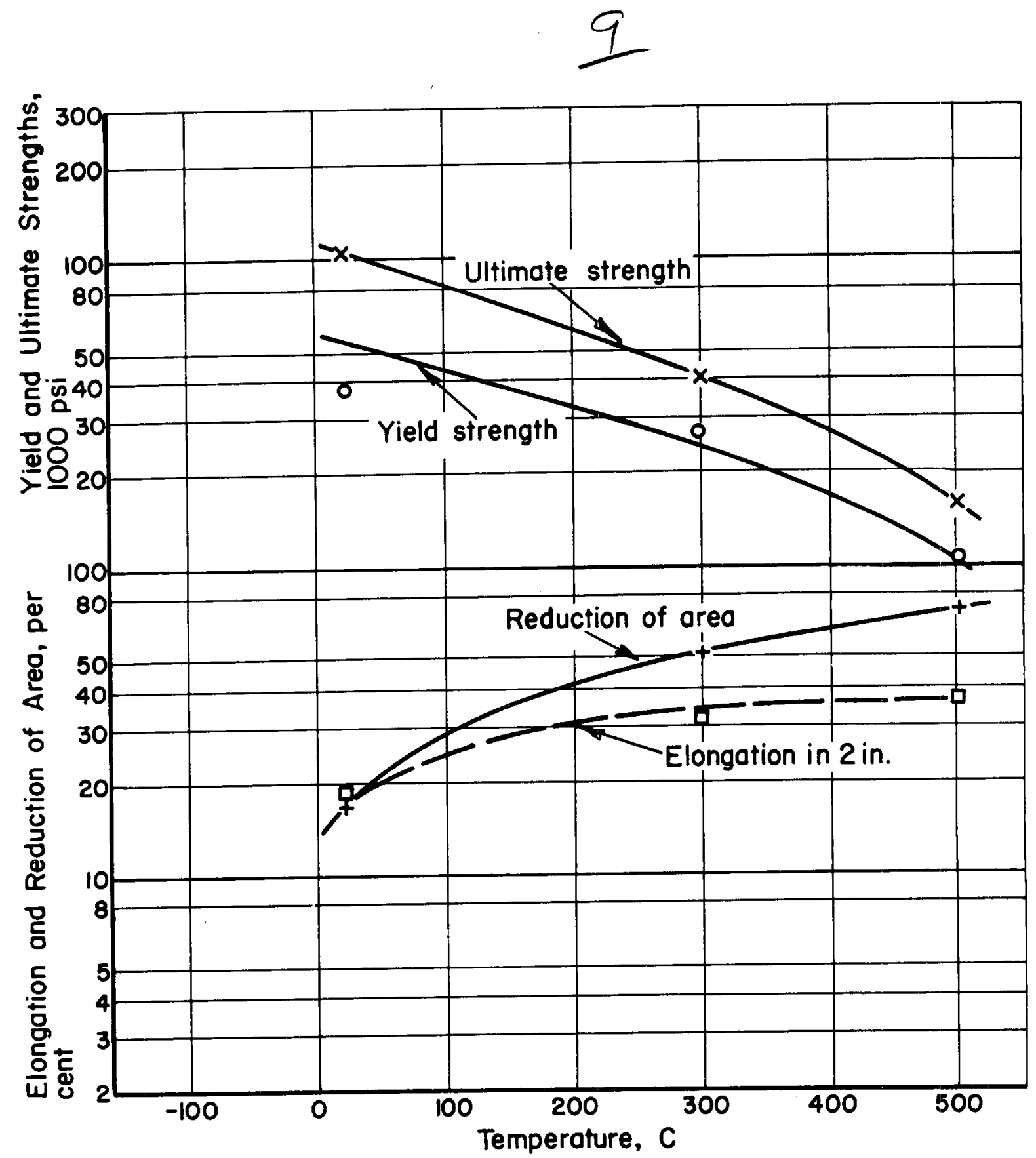

FIGURE 7. TENSILE PROPERTIES OF BETA-QUENCHED, INDUICTIONMELTED URANIUM 


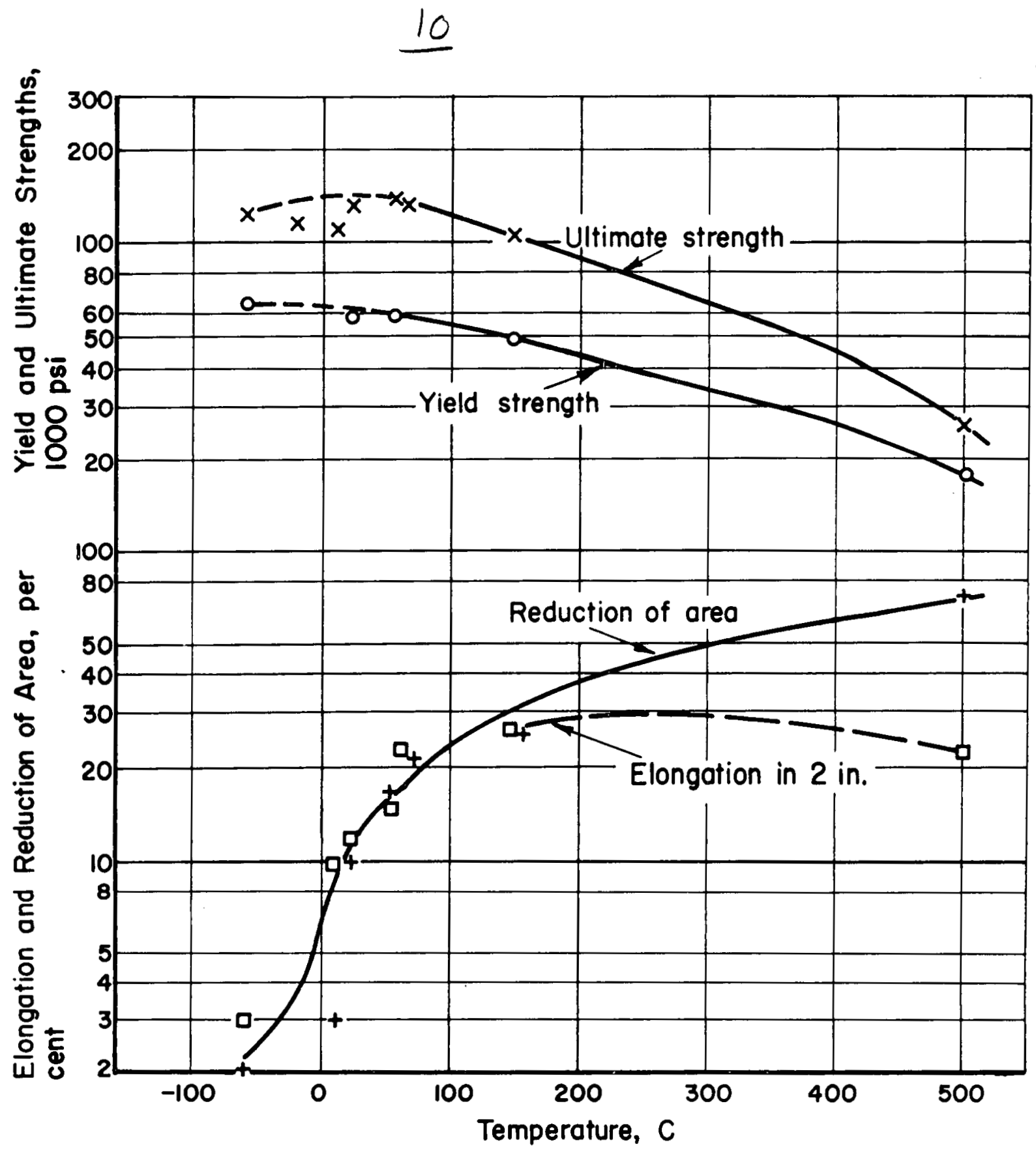

FIGURE 8. TENSILE PROPERTIES OF BETA-TRANSFORMED, ARCMELTED URANIUM-0.35 a $\%$ CHROMIUM ALLOY 
11

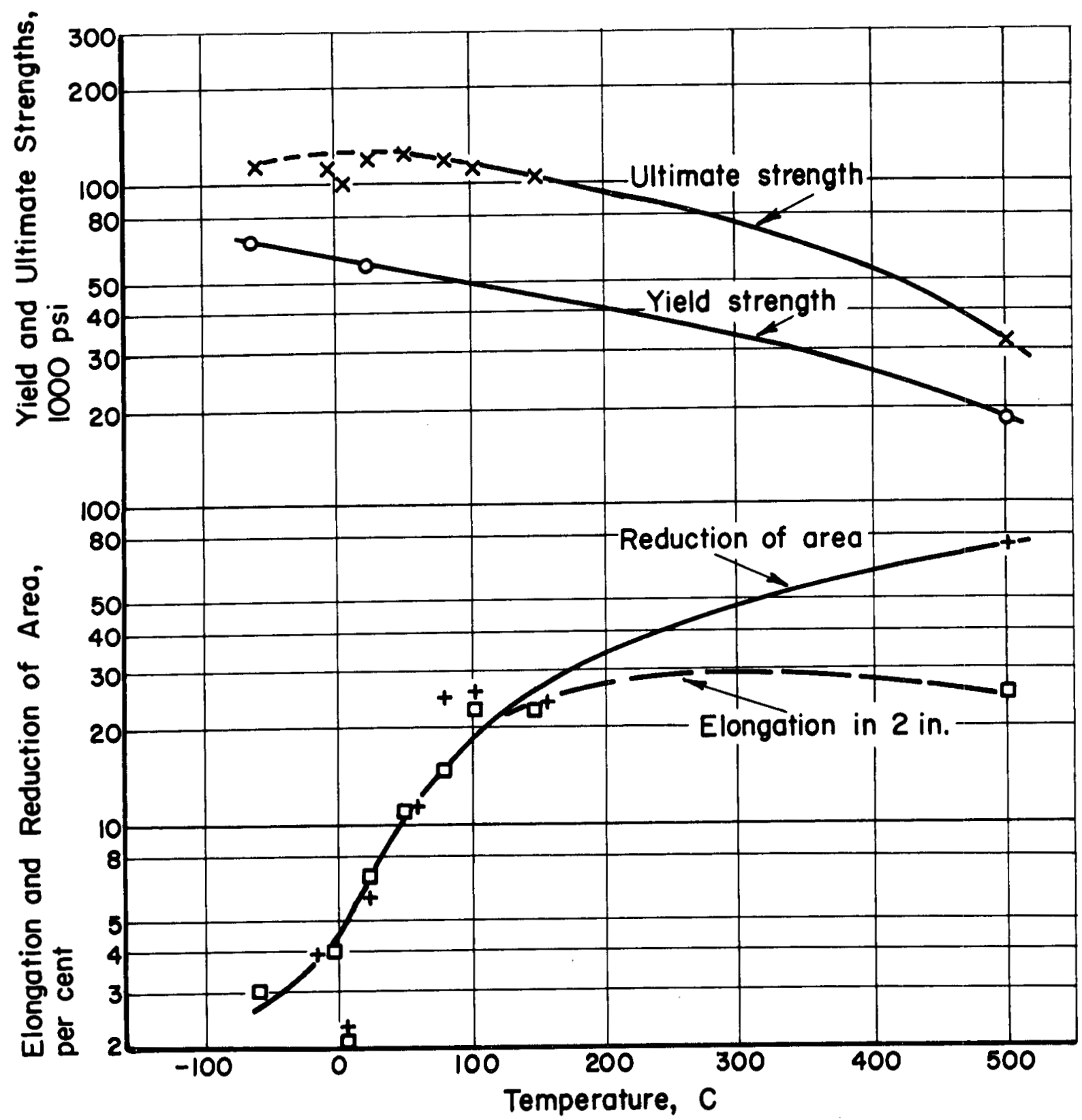

FIGURE 9. TENSILE PROPERTIES OF BETA-QUENCHED, ARC-MELTED URANIUM $-1.5 \%$ \% SILICON ALLOY 
12

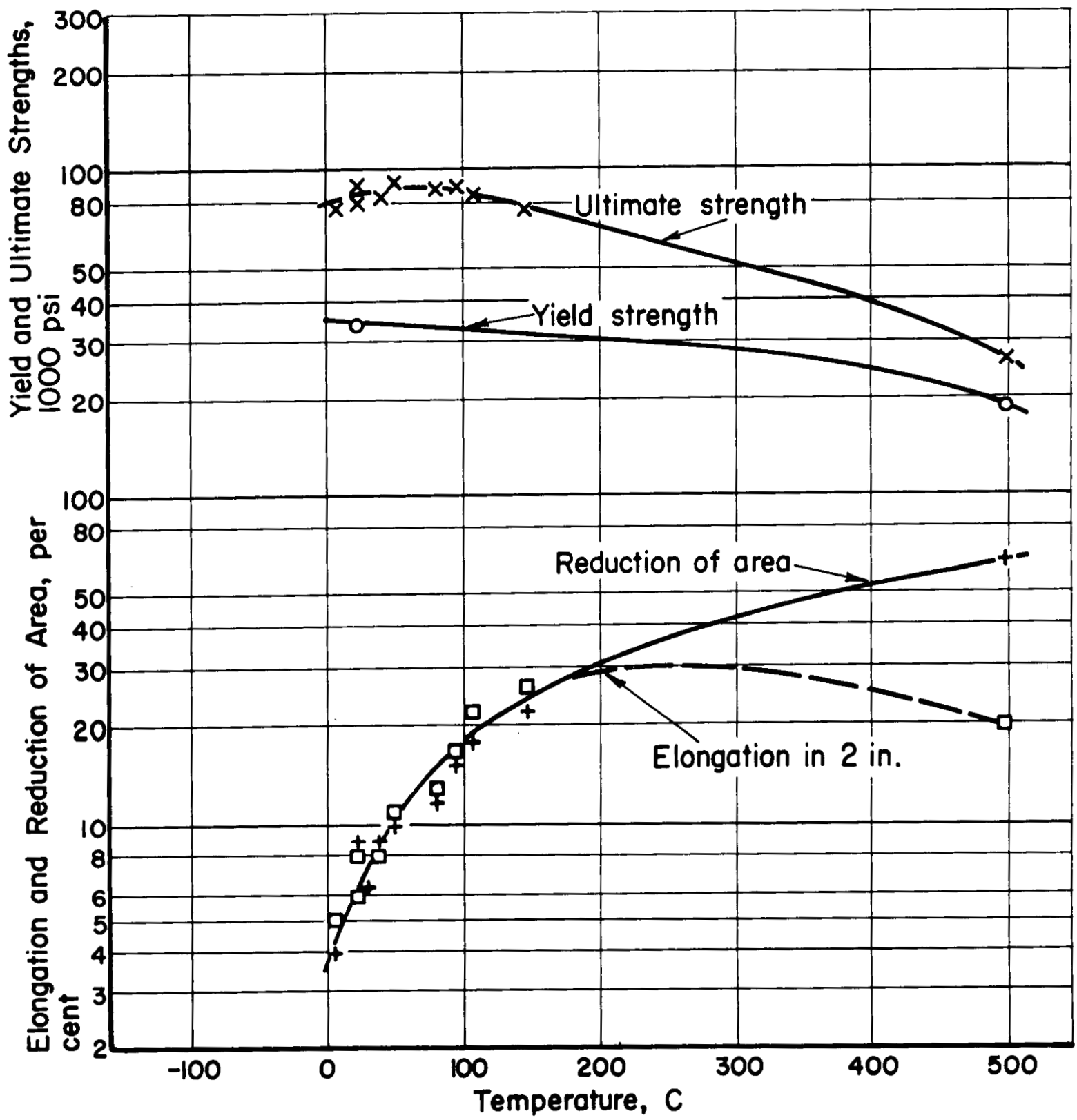

FIGURE 10. TENSILE PROPERTIES OF BETA-QUENCHED, ARC-MELTED URANIUM - $0.5 \%$ a TITANIUM ALLOY 


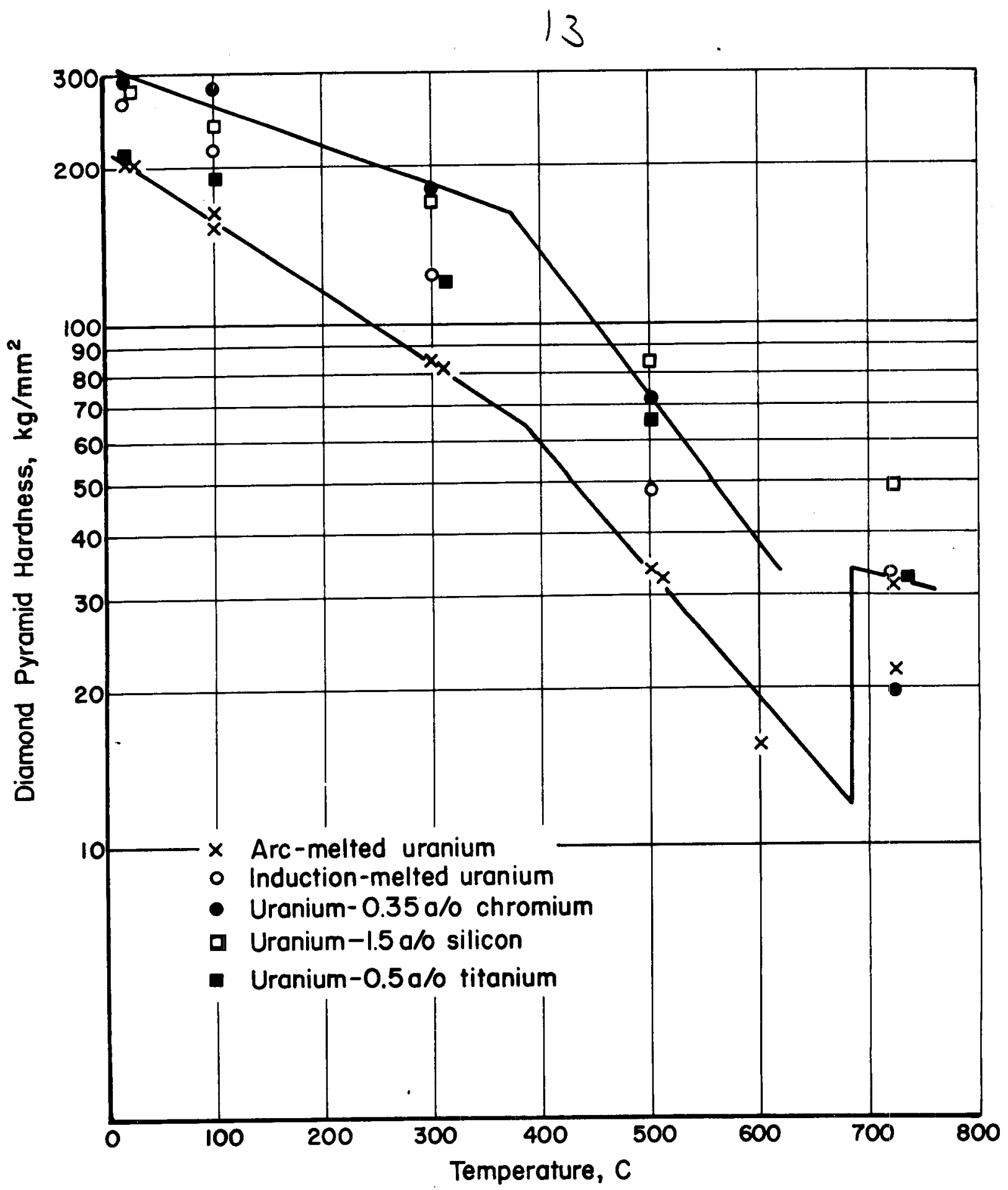

FIGURE II. HARDNESS OF URANIUM ALLOYS AT ELEVATED TEMPERATURES 


\section{4}

two tests on the same specimen, the thermal-expansion characteristics of all the alloys were the same. All alloys showed a linear expansion on heating through the alpha-beta transformation and a linear contraction on cooling through the transformation. On the basis of length of the specimen at room temperature, this change in length on transformation was 0.35 per cent. The mean transformation temperature was $668 \mathrm{C}$. A typical heating or cooling curve is shown in Figure 12. The mean linear-expansion coefficients calculated on the basis of 15 tests on all these alloys are as follow s:

\begin{tabular}{|c|c|c|c|c|c|}
\hline & $\begin{array}{l}20 \text { to } \\
200 \mathrm{C} \\
\end{array}$ & $\begin{array}{l}20 \text { to } \\
300 \mathrm{C} \\
\end{array}$ & $\begin{array}{l}20 \text { to } \\
400 \mathrm{C} \\
\end{array}$ & $\begin{array}{l}20 \text { to } \\
500 \mathrm{C} \\
\end{array}$ & $\begin{array}{l}20 \text { to } \\
600 \mathrm{C} \\
\end{array}$ \\
\hline Coefficient, $10^{-6} \mathrm{in.} / \mathrm{in.} / \mathrm{C}$ : & 14.6 & 15.0 & 15.6 & 16.4 & 17.4 \\
\hline
\end{tabular}

Thermal-conductivity measurements were made by the steady-heatflow method. Temperature gradients along the specimen were compared with temperature gradients along a standard in series with the specimen. The estimated maximum error in the thermal-conductivity values obtained is 5 per cent. The difference between the thermal conductivities of the different alloys was well within this value; hence, small alloying additions seem to have little effect on the thermal conductivity of uranium. A typical thermal-conductivity curve for these alloys is shown as Figure 13.

Electrical-resistivity measurements were obtained only on inductionmelted uranium. This material was heated to $725 \mathrm{C}$ and cooled at a slow rate in the dilatometer prior to the electrical-resistivity tests. Measurements were made by the voltage-drop method; direct current and a standard resistance in series with the specimen were used. The results of this test are shown in Figure 14.

\section{Heat-Treatment Studies}

A variety of heat treatments have been performed on these alloys in an effort to determine the extent to which hardness and grain size can be controlled by heat treatment. All heat treatments were performed on $1 / 2$ in.-diameter bars at least $1 / 2$ in. long. This material was used as hot rolled at $620 \mathrm{C}$. The properties of the bars as hot rolled and as beta treated are shown in Table 2. The structures of the alloys as beta treated are shown in Figures 1, 2, 3, 4, and 5. A noticeable increase in hardness is produced by the beta treatment. This increase is particularly large in the cases of induction-melted uranium and uranium-0.35 a/o chromium alloy.

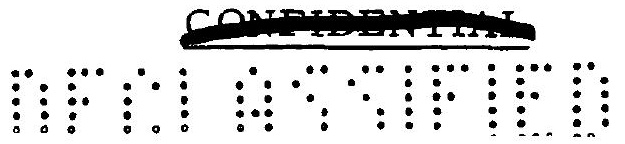






FIGURE 12. LINEAR THERMAL EXPANSION OF URANIUM AND OF BINARY ALLOYS CONTAINING $0.350 / 0$ CHROMIUM, $1.50 \%$ SILICON, OR 0.50\% TITANIUM

CONEIDENTIAL

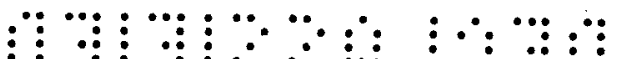




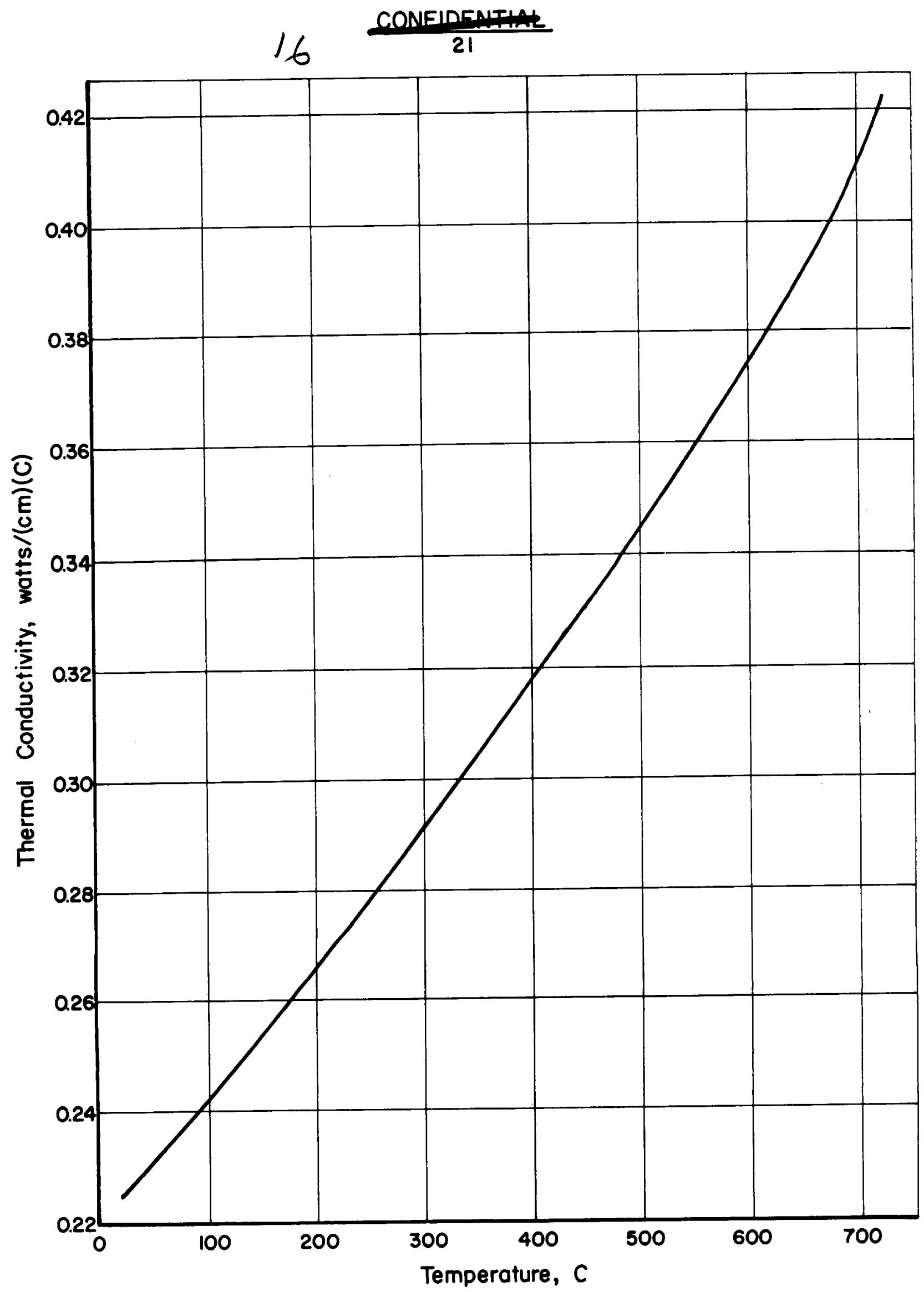

FIGURE 13. THERMAL CONDUCTIVITY OF URANIUM AND OF BINARY ALLOYS CONTAINING 0.350\%CHROMIUM, I.50\% SILICON, OR 0.5a/0 TITANIUM

$\because . . .:$ : : 


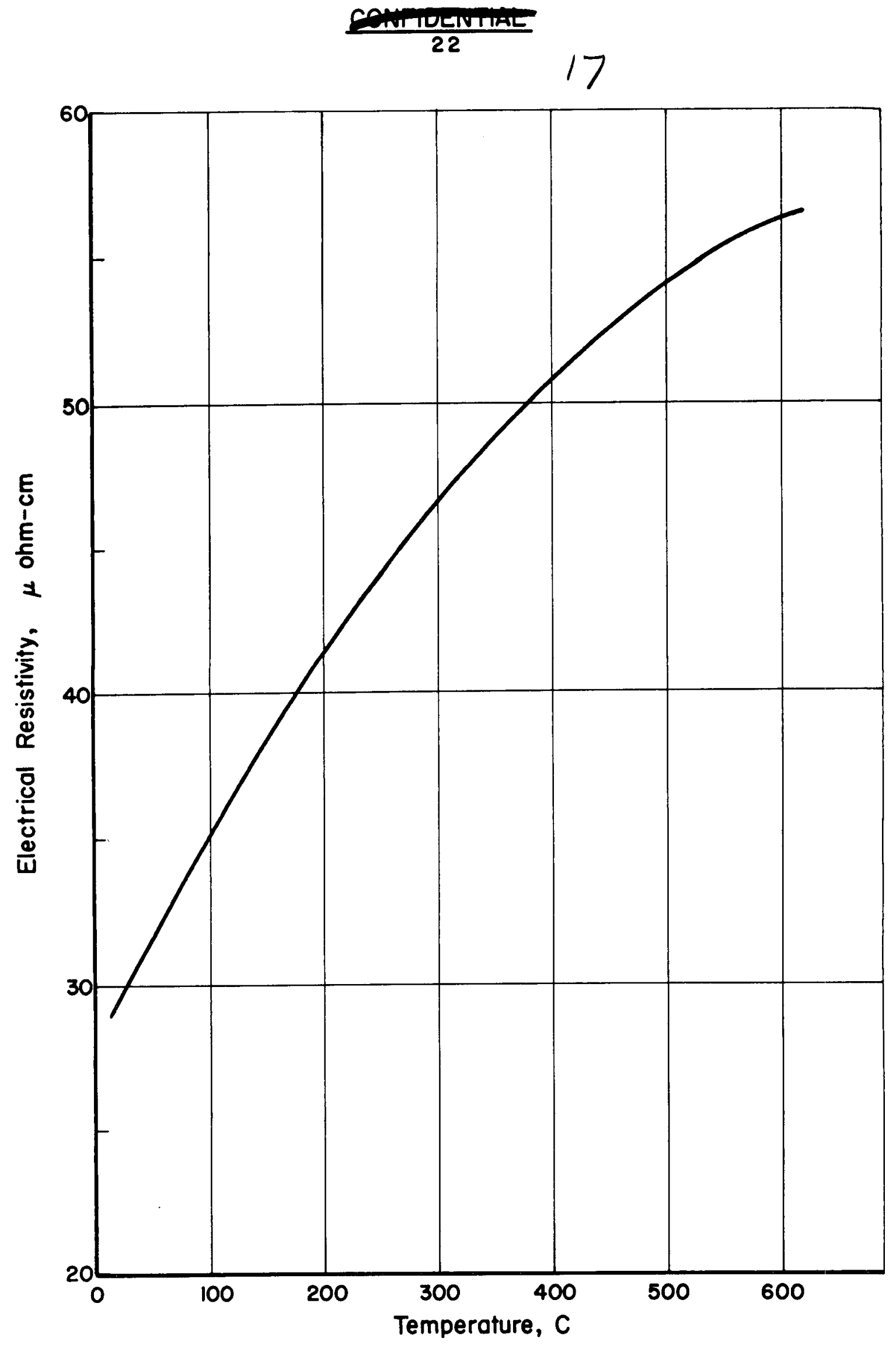

FIGURE 14. ELECTRICAL RESISTIVITY OF INDUCTION-MELTED URANIUM

草 


\section{8}

TABLE 2. PROPERTIES OF AS-ROLLED AND BETA-TREATED URANIUM ALLOYS

\begin{tabular}{lcccc}
\hline \multicolumn{1}{c}{$\begin{array}{c}\text { Alloy } \\
\text { Identification }\end{array}$} & As Rolled at 620 C & \multicolumn{2}{c}{ Beta Treated(a) } \\
\cline { 2 - 4 } & $\begin{array}{c}\text { Hardness, } \\
\text { DPH }\end{array}$ & $\begin{array}{c}\text { Grain Size, } \\
\text { mm }\end{array}$ & $\begin{array}{c}\text { Hardness, } \\
\text { DPH }\end{array}$ & 230 \\
Arc-melted uranium & 194 & 0.05 & 0.10 \\
Induction-melted uranium & 216 & 0.04 & 280 & 0.05 \\
Uranium-0.35 a/o chromium & 206 & 0.04 & 290 & 0.07 \\
Uranium-1.5 a/o silicon & 274 & 0.01 & 295 & 0.04 \\
Uranium-0.5 a/o titanium & 204 & - & 240 & 0.07 \\
\hline
\end{tabular}

(a) Fifteen min at $730 \mathrm{C}$ and then water quenched or isothermally transformed. 
Grain-size measurements were made both by microscopic examination of polished specimens and by macro etching. Macro etching was found to be best suited for grain sizes greater than $0.3 \mathrm{~mm}$, while microscopic examination is best suited to grain sizes smaller than $0.3 \mathrm{~mm}$. In the range of sizes $(0.2$ to $0.5 \mathrm{~mm}$ ) where the two methods of measurement could best be compared, good agreement between the two methods was observed. In this connection, it should be noted that independent observations of grain size on the same specimen by the same method will sometimes vary by as much as 50 per cent. None of the grain-size measurements in this report, at least, should be considered to be more accurate than this. Agreement between macro and micro grain-size measurements was usually, but not always, better than 50 per cent.

Repeating the beta heat treatment by heating to $730 \mathrm{C}$ for $15 \mathrm{~min}$ twice and water quenching twice had no noticeable effect on induction-melted uranium and uranium- $1.5 \mathrm{a} / \mathrm{o}$ silicon alloy. This procedure produced an increase in grain size $(0.10$ to $0.14 \mathrm{~mm}$ ) and a decrease in hardness (230 to $210 \mathrm{DPH})$ in arc-melted uranium. This treatment was not given to the chromium or titanium alloys.

Similarly, air cooling after heating for $15 \mathrm{~min}$ at $730 \mathrm{C}$ had no noticeable effect on induction-melted uranium and uranium-1.5 a/o silicon alloy. This treatment produced an increase in grain size $(0.10$ to $0.20 \mathrm{~mm}$ ) and a decrease in hardness (230 to $208 \mathrm{DPH}$ ) in arc-melted uranium.

Varying the beta treatment and isothermal transformation of the uranium-0.35 a/o chromium alloy produced rather inconclusive results. The effects of several treatments are shown in Table 3 . These results tend to indicate the existence of some sort of age-hardening process occurring during the transformation of the uranium-chromium alloy. The effect on grain size is insignificant, however; and the effect on hardness, while large, is not so great that it might not be produced by variations in the composition of the alloy. However, prior work by D. W. White (KAPL-595, 1951) indicates that the hardness change is real and is caused by a transformation process. The implication of this data is that the chromium alloy with the standard beta treatment is a metallurgically unstable material.

As a final check on the effect of heat treatment upon these alloys, bars of each alloy were end quenched from 730, 800, and $900 \mathrm{C}$. Each bar was $1 / 2 \mathrm{in}$. in diameter and $3 \mathrm{in}$. long. Soaking time at $730 \mathrm{C}$ was $1 \mathrm{hr}$, at $800 \mathrm{C}$ $15 \mathrm{~min}$, and at $900 \mathrm{C} 30 \mathrm{~min}$. At the end of this time the bars were removed from their Vycor capsules and suspended over a 3/8-in.-diameter water jet until cold. Except for one bar, the bars showed no variations in hardness or grain size that could be attributed to the different quenching rates found at various points in the bars. The average grain sizes and hardnesses of the bars are shown in Table 4. These data show no startling effects either upon grain size or hardness as a result of quenching from different temperatures. A slight increase in hardness with increasing quenching temperature

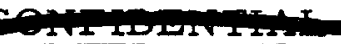


TABLE 3. EFFECT OF HEAT TREATMENT ON THE URANIUM-0.35 a/o CHROMIUM ALLOY

\begin{tabular}{|c|c|c|}
\hline Treatment & $\begin{array}{l}\text { Hardness, } \\
\text { DPH }\end{array}$ & $\begin{array}{l}\text { Grain Size, } \\
\mathrm{mm}\end{array}$ \\
\hline Hot rolled at $620 \mathrm{C}$ & 206 & 0.04 \\
\hline Heated $15 \mathrm{~min}$ at $730 \mathrm{C}$ and water quenched & 275 & 0.07 \\
\hline Heated $15 \mathrm{~min}$ at $730 \mathrm{C}$ and air cooled & 337 & 0.05 \\
\hline $\begin{array}{l}\text { Heated } 15 \mathrm{~min} \text { at } 730 \mathrm{C} \text {, held } 10 \mathrm{~min} \text { at } 500 \mathrm{C} \text {, } \\
\text { and water quenched }\end{array}$ & 322 & 0.05 \\
\hline $\begin{array}{l}\text { Heated } 15 \mathrm{~min} \text { at } 730 \mathrm{C} \text {, held } 20 \mathrm{~min} \text { at } 550 \mathrm{C} \text {, } \\
\text { and water quenched }\end{array}$ & 290 & 0.07 \\
\hline $\begin{array}{l}\text { Heated } 15 \mathrm{~min} \text { at } 730 \mathrm{C} \text {, held } 3 \mathrm{hr} \text { at } 475 \mathrm{C} \text {, } \\
\text { and water quenched }\end{array}$ & 201 & 0.07 \\
\hline $\begin{array}{l}\text { Heated } 15 \mathrm{~min} \text { at } 730 \mathrm{C}, \text { held } 2 \mathrm{hr} \text { at } 550 \mathrm{C} \text {, } \\
\text { and water quenched }\end{array}$ & 202 & 0.07 \\
\hline $\begin{array}{l}\text { Heated } 1 \mathrm{hr} \text { at } 730 \mathrm{C} \text {, water quenched, annealed } \\
\mathrm{l} \mathrm{hr} \text { at } 600 \mathrm{C} \text {, air cooled }\end{array}$ & 220 & 0.20 \\
\hline
\end{tabular}




\section{1}

TABLE 4. EFFECT OF QUENCHING TEMPERATURE ON THE HARDNESS AND GRAIN SIZE OF URANIUM-ALLOY END-QUENCH BARS

\begin{tabular}{|c|c|c|c|c|c|c|}
\hline \multirow[b]{2}{*}{$\begin{array}{c}\text { Alloy } \\
\text { Identification }\end{array}$} & \multicolumn{2}{|c|}{$1 \mathrm{Hr}$ at $730 \mathrm{C}$} & \multicolumn{2}{|c|}{$1 / 4 \mathrm{Hr}$ at $800 \mathrm{C}$} & \multicolumn{2}{|c|}{$1 / 2 \mathrm{Hr}$ at $900 \mathrm{C}$} \\
\hline & $\begin{array}{l}\mathrm{DPH}, \\
\mathrm{kg} / \mathrm{mm}^{2}\end{array}$ & $\begin{array}{c}\text { Grain } \\
\text { Size, } \\
\text { mm }\end{array}$ & $\begin{array}{l}\mathrm{DPH} \\
\mathrm{kg} / \mathrm{mm}^{2}\end{array}$ & $\begin{array}{c}\text { Grain } \\
\text { Size, } \\
\text { mm }\end{array}$ & $\begin{array}{l}\mathrm{DPH}, \\
\mathrm{kg} / \mathrm{mm}^{2}\end{array}$ & $\begin{array}{c}\text { Grain } \\
\text { Size, } \\
\text { mm }\end{array}$ \\
\hline Arc-melted uranium & 243 & 0.40 & 221 & 0.25 & 246 & 0.60 \\
\hline Induction-melted uranium & 338 & 0.10 & 334 & 0.30 & 368 & 0.10 \\
\hline Uranium-0.35 a/o chromium & 258 & 0.20 & 250 & 0.15 & 250 & 0.50 \\
\hline Uranium-1.5 a/o silicon & 314 & 0.10 & 314 & 0.45 & (a) & 0.30 \\
\hline Uranium-0.5 a/o titanium & 259 & 0.30 & 247 & 0.20 & 302 & 0.50 \\
\hline
\end{tabular}

(a) See Figure 15. 


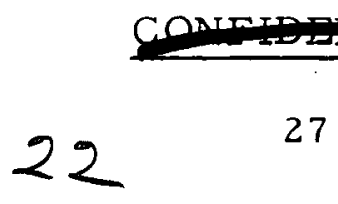

is evident in some of the alloys, and probably is caused by the increased thermal stresses produced in quenching from higher temperatures. A comparison of Table 2 with Table 4 will show a pronounced increase in grain size with time at $730 \mathrm{C}$. All bars showed a tendency to form large columnar grains radiating away from the quenched end. These grains were perhaps $0.1 \mathrm{in}$. long in the bars quenched from $730 \mathrm{C}$, but were at least $0.25 \mathrm{in}$. long in the bars quenched from $900 \mathrm{C}$.

The uranium-1.5 a/o silicon alloy showed a pronounced-hardness response when end quenched from $900 \mathrm{C}$. The hardness traverse on this bar is shown in Figure 15. The microstructure of this bar showed two unique features. Severe cracks were present in the bar for a distance of $3 / 8$ in. from the quenched end, and silicides were not present at the quenched end, but were present $3 / 4$ in. from the quenched end. The precipitation rate of the silicide is evidently very rapid, and the hardness of the quenched end of the bar is probably the result of the presence of silicon in supersaturated solution. Figures $16 \mathrm{a}$ and $16 \mathrm{~b}$ show the as-polished structure of the bar near the quenched end and $3 / 4$ in. from the end respectively.

The bars quenched from $800 \mathrm{C}$ were aged for $2 \mathrm{hr}$ at $400 \mathrm{C}$. This treatment produced no noticeable effect upon either hardness or grain size.

The bars quenched from $730 \mathrm{C}$ and $900 \mathrm{C}$ were annealed for $1 \mathrm{hr}$ at $600 \mathrm{C}$. This treatment produced a marked decrease in the hardness of the alloy bars but practically no change in grain size. The measurements indicate that a slight decrease in grain size of arc-melted uranium also resulted from this treatment, but this effect probably arises from the difficulty in estimating beta-quench grain sizes as compared with the relative ease of estimating alpha-recrystallized grain sizes. These results are shown in Table 5. Annealing at $600 \mathrm{C}$ returns the hardnesses to values close to those of the alloys in their hot-rolled condition.

Annealing of the silicon alloy at $600 \mathrm{C}$ had no effect on the quench cracks near the quenched end of the bar end quenched from $900 \mathrm{C}$. These cracks made determination of the annealed structure very difficult, but as nearly as could be determined the annealed structure corresponds closely with that of Figure 16b. The tendency of the silicon alloy to crack when water quenched from $900 \mathrm{C}$ eliminates any practical treatment involving solution of the silicide and subsequent aging, since less drastic quenching rates do not retain the silicide in solution. 
23

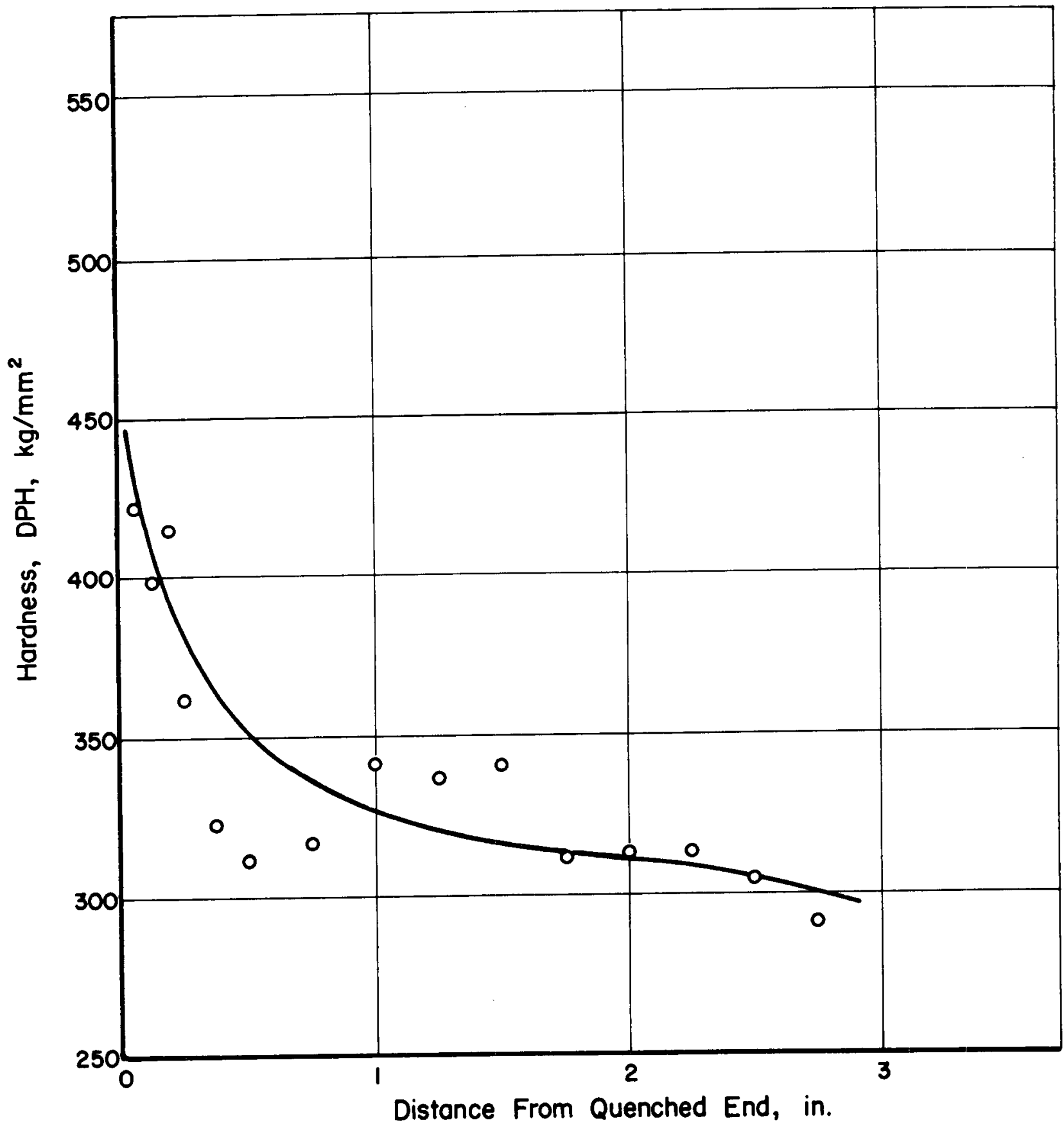

FIGURE 15. HARDNESS TRAVERSE ON URANIUM-1.5 a/0 SILICON ALLOY END QUENCHED FROM $900 \mathrm{C}$ 


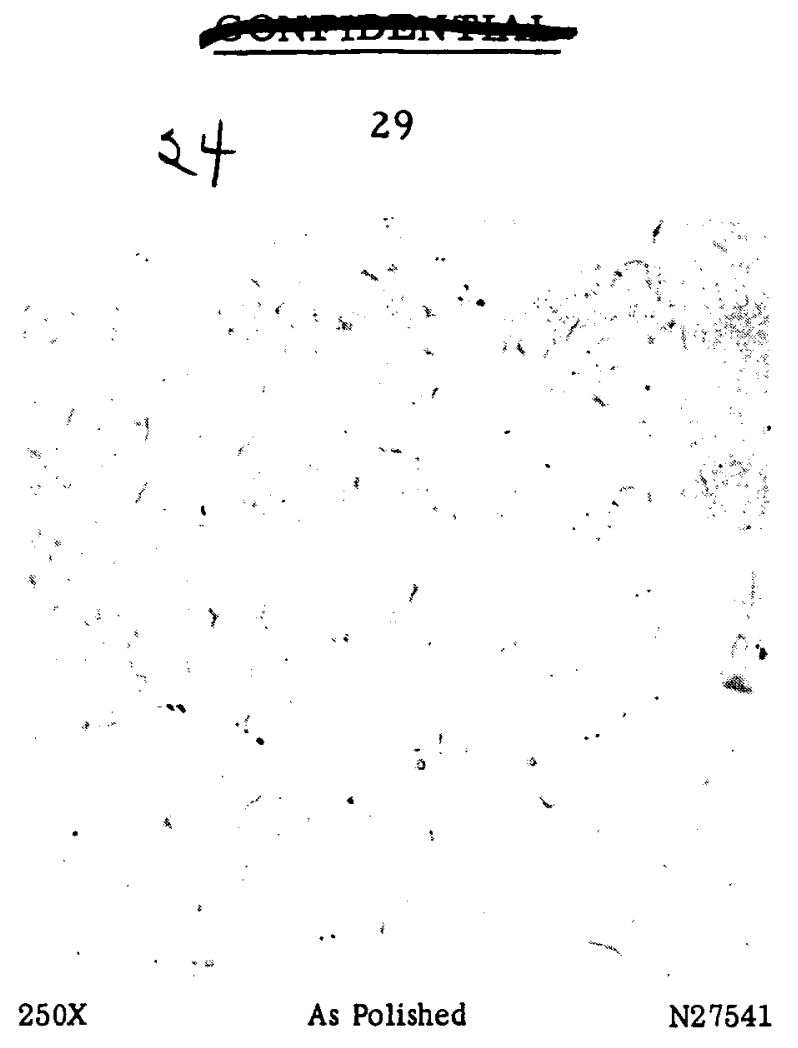

a. Quenched End

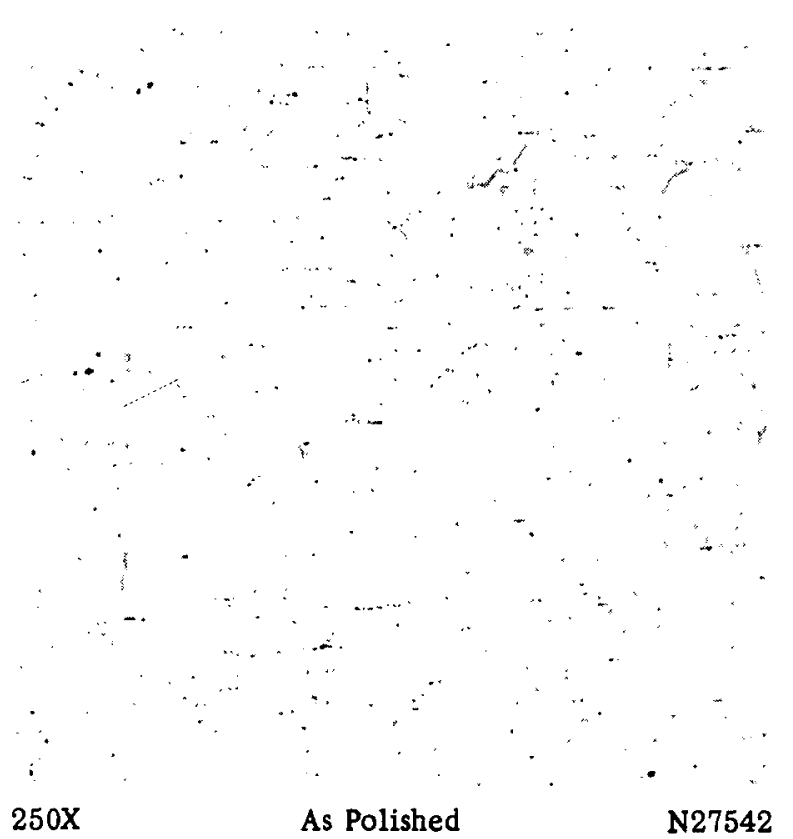

b. $3 / 4 \mathrm{In}$. From Quenched End

FIGURE 16. ARC-MELTED URANIUM-1.5 a/o SILICON ALLOY END QUENCHED AFTER 1/2 HR AT 900 C

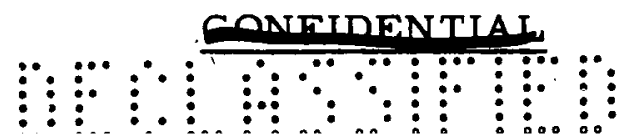




\section{5}

TABLE 5. EFFECT OF ANNEALING AT $600 \mathrm{C}$ ON THE HARDNESS AND GRAIIN SIZE OF QUENCHED-URANIUM ALLOYS

\begin{tabular}{|c|c|c|c|c|}
\hline \multirow[b]{2}{*}{$\begin{array}{c}\text { Alloy } \\
\text { Identification }\end{array}$} & \multicolumn{2}{|c|}{$\begin{array}{c}1 \mathrm{Hr} \text { at } \\
730 \mathrm{C}, \\
\text { Water Quenched }\end{array}$} & \multicolumn{2}{|c|}{$\begin{array}{c}1 \mathrm{Hr} \text { at } 730 \mathrm{C}, \\
\text { Water Quenched, } \\
\text { Annealed } 1 \mathrm{Hr} \text { at } 600 \mathrm{C}\end{array}$} \\
\hline & $\begin{array}{c}\mathrm{DPH} \\
\mathrm{kg} / \mathrm{mm}^{2}\end{array}$ & $\begin{array}{c}\text { Grain Size, } \\
\text { mm }\end{array}$ & $\begin{array}{c}\text { DPH, } \\
\mathrm{kg} / \mathrm{mm}^{2}\end{array}$ & $\begin{array}{c}\text { Grain Size, } \\
\mathrm{mm}\end{array}$ \\
\hline Arc-melted uranium & 243 & 0.40 & 205 & 0.15 \\
\hline Induction-melted uranium & 338 & 0.10 & 278 & 0.10 \\
\hline Uranium $-0.35 \mathrm{a} / \mathrm{o}$ chromium & 258 & 0.20 & 220 & 0.20 \\
\hline Uranium-1.5 a/o silicon & 314 & 0.10 & 279 & 0.10 \\
\hline \multirow[t]{3}{*}{ Uranium-0.5 a/o titanium } & 259 & 0.30 & 212 & 0.30 \\
\hline & \multicolumn{2}{|c|}{$\begin{array}{l}1 / 2 \mathrm{Hr} \text { at } \\
900 \mathrm{C}, \\
\text { ater Quenched }\end{array}$} & \multicolumn{2}{|c|}{$\begin{array}{c}1 / 2 \mathrm{Hr} \text { at } 900 \mathrm{C}, \\
\text { Water Quenched, } \\
\text { Annealed } 1 \mathrm{Hr} \text { at } 600 \mathrm{C}\end{array}$} \\
\hline & $\begin{array}{l}\mathrm{DPH}, \\
\mathrm{kg} / \mathrm{mm}^{2} \\
\end{array}$ & $\begin{array}{c}\text { Grain Size, } \\
\mathrm{mm} \\
\end{array}$ & $\begin{array}{c}\mathrm{DPH}, \\
\mathrm{kg} / \mathrm{mm}^{2} \\
\end{array}$ & $\begin{array}{c}\text { Grain Size, } \\
\mathrm{mm} \\
\end{array}$ \\
\hline Arc-melted uranium & 246 & 0.60 & 207 & 0.50 \\
\hline Induction-melted uranium & 368 & 0.10 & 276 & 0.10 \\
\hline Uranium-0.35 a/o chromium & 250 & 0.50 & 223 & 0.50 \\
\hline Uranium- $1.5 \mathrm{a} / \mathrm{o}$ silicon & (a) & 0.30 & 299 & 0.50 \\
\hline Uranium $-0.5 \mathrm{a} / \mathrm{o}$ titanium & 302 & 0.50 & 228 & 0.20 \\
\hline
\end{tabular}

(a) See Figure 15. 
31 and 32

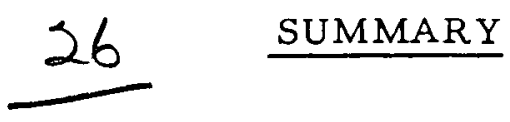

The five uranium alloys investigated in detail are distinguishable mainly by differences in their mechanical properties. Arc-melted biscuit uranium is notable for its high purity, low-inclusion count, somewhat larger grain size, and somewhat lower strength and hardness. The arc-melted uranium-0.35 a/o chromium alloy is notable for its high strength and ductility in the beta-treated condition. The high hardness of the chromium alloy with the standard beta treatment indicates that it is a metallurgically unstable material as compared with the same alloy when alpha annealed. The arc-melted uranium-1.5 a/o silicon alloy is notable for its high strength and low ductility at room temperature. The arc-melted uranium$0.5 \mathrm{a} / 0$ titanium alloy has little to recommend it, since the titanium is probably present as titanium carbide and the alloy is no stronger than uranium at room temperature.

Measurements showed no significant differences between the thermal expansion and thermal conductivities of the five alloys.

An examination of the heat-treatment behavior of the five uranium alloys disclosed that the usual beta-treatment results in grain coarsening and an increase in hardness as compared with the grain size and hardness of the alpha-rolled materials. The increase in hardness is particularly large in the cases of induction-melted uranium and arc-melted uranium$0.35 \mathrm{a} / \mathrm{o} \mathrm{chromium} \mathrm{alloy.} \mathrm{The} \mathrm{beta} \mathrm{treatment} \mathrm{is} \mathrm{justifiable} \mathrm{as} \mathrm{a} \mathrm{method} \mathrm{of}$ removing preferred orientation produced in hot rolling, but results in ragged grains which are an indication of metallurgical instability. Treating at higher temperatures results in larger increases in grain size and hardness. Annealing for $\mathrm{l} \mathrm{hr}$ at $600 \mathrm{C}$ after beta treating restores the hardnesses to values close to the alpha-rolled values. This treatment tends to result in equiaxed grains and produces no significant change in grain size.

\section{ACKNOW LEDGEMENTS}

The authors are indebted to A. A. Bauer and J. M. Fackelmann for following the alloys through the fabrication procedures and for performing most of the initial heat treatments. The tensile tests were carried out under the direction of L. L. Marsh, Jr. The physicai-property measurements were made by $H$. M. Deem and the photomicrographs were prepared by D. M. Cheney.

HAS:FAR:WC/mmk

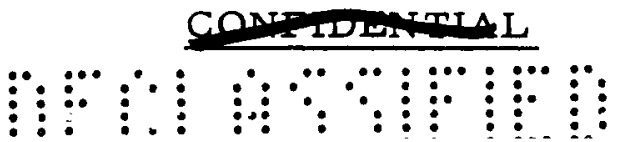




$$
0-26
$$

$\therefore$ 